\title{
Production, transport, maturation, storage and survival of spermatozoa in the male Japanese quail, Coturnix coturnix
}

\author{
J. Clulow and R. C. Jones
}

Department of Biological Sciences, University of Newcastle, New South Wales 2308, Australia

\begin{abstract}
Summary. Male Japanese quail have relatively large testes $(2 \cdot 26 \%$ of body weight), a rapid rate of spermatogenesis (14.4-15.8 days) and an efficient production of spermatozoa $\left(92.5 \times 10^{6} / \mathrm{g}\right.$ testis per day). The daily output of spermatozoa is high $\left(308 \times 10^{6}\right.$ per bird, $2.08 \times 10^{6}$ per $\mathrm{g}$ body weight). The total number of extragonadal spermatozoa was $308 \pm 22 \times 10^{6}$ per bird. Spermatozoa were transported through the genital ducts in about 1 day, maturing quickly in the epididymal region and stored briefly in the ductus deferens. Spermatozoa isolated in the ductus deferens by ligatures around the duct rapidly lost the capacity for motility after 3 days. It is concluded that, compared to mammals such as the rat, the reproductive strategy of the quail involves the rapid production, maturation and transport of spermatozoa through the reproductive tract, in association with a limited capacity to store spermatozoa for long periods within the male genital ducts.
\end{abstract}

\section{Introduction}

There have been a number of recent studies on the male genital ducts of several avian species (domestic fowl: Tingari, 1971, 1972; domestic turkey: Hess, Thurston \& Biellier, 1976; Hess \& Thurston, 1977; Japanese quail: Aire, 1979, 1980). However, the main reports of functional studies are by Munro $(1938 \mathrm{a}, \mathrm{b})$ who studied the transport, maturation and storage of spermatozoa in the domestic fowl. Bedford (1979) has given some data for several avian species to demonstrate differences in sperm maturation between passerine and non-passerine birds.

The studies described in this report were carried out as part of a general study of reproductive strategies of male vertebrates. We are examining the structure and function of the reproductive system (particularly the genital ducts) of the Japanese quail because it is the most suitable laboratory bird available.

\section{Materials and Methods}

Sexually mature males ( $>8$ weeks of age) were used for all studies. They were maintained with females in animal rooms kept between 20 and $26^{\circ} \mathrm{C}$ with a constant light regimen of $16 \mathrm{~h}$ light $(06: 00-22: 00 \mathrm{~h}) / 24 \mathrm{~h}$ for a period of at least 3 weeks before use and during the experiment when appropriate. The birds were killed by decapitation. In most studies the genital ducts were divided into the six sampling regions shown in Text-fig. 1 . When appropriate analyses of variance were 
carried out on data (scores of percentage motile spermatozoa were transformed to angles) to test the statistical significance of treatment effects.

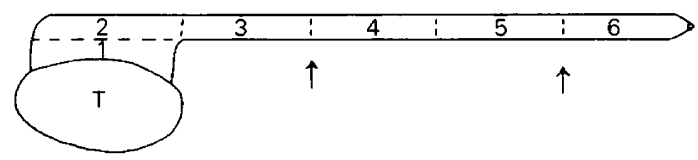

Text-fig. 1. Diagrammatic presentation (lateral aspect) of a testis $(T)$ and genital ducts of the male Japanese quail showing the division of the genital ducts into 6 sampling regions. Regions 1 and 2 occur in the part of the genital ducts adjacent to the testis (epididymal region). Regions 3-6 are divisions, of equal length between the epididymal region and cloaca, along the cord formed by the convoluted ductus deferens within its connective tissue stroma. Arrows indicate where the ductus deferens was ligated to isolate spermatozoa within the duct.

Gonadal index. Testes and body weights of 18 birds were obtained to estimate the gonadal index ((weight of both testes $\times 100)$ /body weight) and to compare the weights of the left and right testes.

Number and distribution of extragonadal spermatozoa. The left genital ducts were removed from each of 16 animals and divided into the six regions described above. Each region was homogenized (Sorvall Omni-mixer) for $1.5 \mathrm{~min}$ in $2 \mathrm{ml}$ of a solution of $250 \mathrm{~mm}$-sucrose and 6 mM-sodium hydroxide. The process produced a clear suspension of intact sperm heads which were easily distinguished under a microscope. A sub-sample of each homogenate was examined in a Neubauer haemocytometer to determine the total number of spermatozoa in the $2 \mathrm{ml}$ homogenate. The total number of extragonadal spermatozoa per animal was estimated by doubling the total value obtained for the left genital ducts.

Duration of sperm transport. The duration of transport of spermatozoa through the genital ducts was determined using animals killed at various times (Table 2) after the injection of $\left[{ }^{3} \mathrm{H}\right]$ thymidine and carrying out autoradiography of homogenates of the ducts. Intraperitoneal injections of $\left[\right.$ methyl $-{ }^{3} \mathrm{H}$ ]thymidine (sp. act. $25 \mathrm{Ci} / \mathrm{mmol}$; Radiochemical Centre, Amersham, U.K.) were administered at a dose of $2 \mu \mathrm{Ci} / \mathrm{g}$ body weight at $06: 00 \mathrm{~h}$ (start of the light period). After killing, small sub-samples $(20-40 \mu \mathrm{l})$ of homogenates of each region of the genital ducts were mixed with 1 or 2 drops of cacodylate-buffered formalin (150 mM-sodium cacodylate, $\mathrm{pH}$ $7.3)$ and smeared and air-dried on microscope slides coated with $2 \%(\mathrm{w} / \mathrm{v})$ agarose (Calbiochem, San Diego, U.S.A.). The slides were then coated with photographic emulsion (L4 nuclear research emulsion, Ilford Ltd, Ilford, U.K.) and maintained in the dark for 4 weeks at $4^{\circ} \mathrm{C}$. They were developed in a $50 \%$ solution of Dektol (Kodak, Rochester, U.S.A.) for 2 min at $20^{\circ} \mathrm{C}$. Permanent mounts were prepared in Euparal (GBI Laboratories, Manchester, U.K.). A total of 100 spermatozoa was counted in the homogenate of each site and the results are expressed as the mean percentages of labelled spermatozoa; spermatozoa were scored as labelled if their heads had $\geqslant 5$ autoradiographic grains than did a similar area of background.

The time which spermatozoa spent passing through each region of the genital ducts was estimated from the distribution of extragonadal spermatozoa, assuming that relative to the total transit time the period spent in each region of the genital ducts is proportional to the occurrence of extragonadal spermatozoa in the region (Robb, Amann \& Killian, 1978).

- Duration of spermatogenesis. The interval between the injection of $\left[{ }^{3} \mathrm{H}\right]$ thymidine and the earliest occurrence of labelled spermatozoa in the genital ducts (estimated in the experiment described above) was used to estimate the period between the occurrence of preleptotene and leptotene spermatocytes, and the completion of spermatogenesis (de Reviers, 1968).

Rate of production of spermatozoa. The daily production of spermatozoa by the testes was calculated (Orgebin-Crist, 1965) as no. of extragonadal spermatozoa/duration of transport through the ducts.

Development of motility. The development by spermatozoa of the capacity for motility 
during passage through the genital ducts was investigated in preparations of spermatozoa released from the testis and in four regions of the genital ducts. Small tissue samples $\left(2-5 \mathrm{~mm}^{3}\right)$ from each region were macerated under water-saturated paraffin oil (Fisher Scientific Co., Fair Lawn, New Jersey, U.S.A.) in an incubation medium of $\mathrm{Ca}^{2+}$-free Krebs-Ringer phosphate, $\mathrm{pH}$ 7.4 (Umbreit, Burris \& Stauffer, 1972), containing $1 \mathrm{mg}$ bovine serum albumin (Commonwealth Serum Laboratories, Melbourne, Australia) $/ \mathrm{ml}$ at $37^{\circ} \mathrm{C}$. Sub-samples were taken after incubation for $0,0.5$ and $1.5 \mathrm{~h}$ and the activity of spermatozoa was assessed in wet mounts between a microscope slide and coverslip, using a phase-contrast microscope at $\times 400$ magnification. Two scores were made of the activity of spermatozoa: the percentage of motile spermatozoa and the degree of progressive motility. The latter was scored on a scale of 0 to 4 (Emmens, 1947) where 0 represents no motility and 4 represents vigorous motility. However, as the interpretation of the results for both types of score were very similar, only the scores of percentage motile spermatozoa are presented in this report.

Survival of spermatozoa in the ligated ductus deferens. Birds were anaesthetized by intraperitoneal administration of pentobarbitone sodium (Nembutal: Abbott Laboratories, Sydney, Australia) at a dose of $60-75 \mathrm{mg} / \mathrm{kg}$. The abdomen was opened by a longitudinal incision on the ventral surface lateral to the mid-line of the body. With the aid of an operating microscope (OPMI 1 Zeiss, West Germany) the viscera were deflected with a sterile spatula and a 3-4-cm length of the left ductus deferens (Text-fig. 1) was isolated using silk ligatures (earliest replicates) or (in later replicates) haemoclips (Edward Weck \& Co. Inc., Durham, North Carolina, U.S.A.); there was no difference in the response to the two methods. Care was taken to ligate only the ductus deferens and to avoid constriction of major blood vessels. In each bird the contralateral ductus deferens was left unligated as a control. However, to assess the effect of the operation, unoperated (control) animals were also examined. The quail were killed at various times after the operation and samples from the isolated ductus deferens and from the equivalent region of the unoperated contralateral ductus deferens were minced in Krebs-Ringer phosphate. The motility of spermatozoa was assessed microscopically as described above. To determine whether the integrity of the epithelium of the ductus deferens was adversely affected by the operation, samples of ligated and unligated ductus deferentes were prepared (6 animals) for examination with the light microscope by fixing in Bouin's fluid, embedding in Paraplast (Brunswick Co., St Louis, Missouri, U.S.A.), sectioning at $5 \mu \mathrm{m}$ and staining with haematoxylin and eosin.

\section{Results}

\section{Size of gonads and distribution of extragonadal spermatozoa}

The mean ( \pm s.e.m.) body, and left and right testicular weights of 16 quail were respectively $147.8 \pm 4.2 \mathrm{~g}, 1.71 \pm 0.08 \mathrm{~g}$ and $1.62 \pm 0.09 \mathrm{~g}$. There was no statistically significant difference in the mean weights of the left and right testes. The gonadal index (see 'Materials and Methods') for the quail was $2 \cdot 26 \pm 0 \cdot 01$.

The total number and distribution of spermatozoa in the genital ducts of the quail is shown in Table 1 . Only $8 \%$ of the extragonadal spermatozoa were present within the epididymal region. The rest were fairly evenly distributed along the ductus deferens. The total number of extragonadal spermatozoa per bird was $308 \times 10^{6} \pm 22 \times 10^{6}$ (mean \pm s.e.m.).

\section{Spermatogenesis, and daily production and transport of spermatozoa}

Some variation between individuals in the time when labelled spermatozoa were released into the extragonadal genital ducts (a range of about $12 \mathrm{~h}$ ) precludes an accurate estimate of the duration of spermatogenesis. Assuming that spermatozoa entered the genital ducts between $9 \cdot 5$ 
Table 1. Determinations of the distribution and estimates of the duration of transport of spermatozoa in different regions of the genital ducts of male quail (see Text-fig. 1)

\begin{tabular}{|c|c|c|c|c|c|c|}
\hline & \multicolumn{2}{|c|}{ Epididymal region } & \multicolumn{4}{|c|}{ Ductus deferens } \\
\hline & Region 1 & Region 2 & Region 3 & Region 4 & Region 5 & Region 6 \\
\hline $\begin{array}{l}\text { No. of spermatozoa/side }\left(10^{6}\right) \\
\text { Duration of sperm } \\
\text { transit (h) }\end{array}$ & $\begin{array}{c}1.8 \pm 0.3 \\
0.3\end{array}$ & $\begin{array}{c}9.9 \pm 1.9 \\
1.5\end{array}$ & $\begin{array}{c}45 \cdot 4 \pm 3.5 \\
7 \cdot 1\end{array}$ & $\begin{array}{c}36 \cdot 8 \pm 2 \cdot 8 \\
5.7\end{array}$ & $\begin{array}{c}28 \cdot 6 \pm 3 \cdot 1 \\
4 \cdot 5\end{array}$ & $\begin{array}{c}31.4 \pm 3.9 \\
4.9\end{array}$ \\
\hline
\end{tabular}

Values are means \pm s.e.m. for 16 birds.

and 10.5 days after the injection of $\left[{ }^{3} \mathrm{H}\right]$ thymidine (Table 2 ) and that the spermatozoa labelled in the autoradiographs were derived from preleptotene and leptotene spermatocytes (de Reviers, 1968), the interval between the occurrence of preleptotene and leptotene spermatocytes and the completion of spermatogenesis was between 9.5 and 10.5 days.

The period between the most frequent number (mode) of labelled spermatozoa entering and leaving the ducts was used as an estimate of the average duration of transport of spermatozoa through the genital ducts (Table 2). Assuming that the mode number of labelled spermatozoa entered the ducts shortly after Day 10.5 (the location of the mode at site 3 was 11.0 days and at site 6 it was 11.5 days after injection) it was considered that the mode of the distribution of labelled spermatozoa traversed the genital ducts in about 1 day. The period taken for the fastest spermatozoa to pass through the genital ducts was also estimated to be about 1 day because labelled spermatozoa were first detected at sites 1 and 6 of the ducts at 10.0 and 11.0 days respectively after the injection of $\left[{ }^{3} \mathrm{H}\right]$ thymidine (Table 2 ).

Table 2. The mean ( \pm s.e.m.) percentage of spermatozoa labelled in autoradiographs of homogenates from regions 1-6 of the genital ducts (see Text-fig. 1) of the male Japanese quail prepared at various times after the injection of $\left[{ }^{3} \mathrm{H}\right]$ thymidine

\begin{tabular}{|c|c|c|c|c|c|c|c|c|}
\hline \multirow{2}{*}{$\begin{array}{l}\text { Day after } \\
\text { injection }\end{array}$} & \multirow[b]{2}{*}{$\mathrm{N}^{*}$} & \multicolumn{6}{|c|}{ \% labelled spermatozoa at each site } & \multirow{2}{*}{$\begin{array}{l}\text { No. of birds } \\
\text { with labelled } \\
\text { spermatozoa } \\
\text { in genital } \\
\text { ducts }\end{array}$} \\
\hline & & 1 & 2 & 3 & 4 & 5 & 6 & \\
\hline$\leqslant 9.5$ & 6 & 0 & 0 & 0 & 0 & 0 & 0 & 0 \\
\hline $10 \cdot 0$ & 5 & $2.2 \pm 1.5$ & 0 & $0.2 \pm 0.2$ & 0 & 0 & 0 & 3 \\
\hline $10 \cdot 5$ & 5 & $26.4 \pm 12.4$ & $27.4 \pm 14.4$ & $6.2 \pm 3.8$ & $1.0 \pm 1.0$ & 0 & 0 & 5 \\
\hline 11.0 & 5 & $28.2 \pm 13.9$ & $37.2 \pm 17.4$ & $45 \cdot 8 \pm 9 \cdot 5$ & $37.2 \pm 15 \cdot 8$ & $15 \cdot 4 \pm 9 \cdot 6$ & $2 \cdot 6 \pm 2 \cdot 4$ & 5 \\
\hline 11.5 & 4 & $3 \cdot 3 \pm 1 \cdot 1$ & $1.3 \pm 0.8$ & $3 \cdot 5 \pm 2 \cdot 5$ & $25 \cdot 3 \pm 11 \cdot 6$ & $49 \cdot 0 \pm 16 \cdot 2$ & $56.5 \pm 6 \cdot 0$ & 4 \\
\hline $12 \cdot 0$ & 2 & $1.0 \pm 0$ & $\overline{0}$ & 0 & $\overline{0}$ & $1.5 \pm 0.5$ & $21 \cdot 5 \pm 1 \cdot 5$ & 2 \\
\hline
\end{tabular}

* $\mathrm{N}=$ no. of birds killed at each time; 100 spermatozoa were counted per site per animal.

Estimates of transit times for spermatozoa through each region of the genital ducts are shown in Table 1. Spermatozoa spent only about $2 \mathrm{~h}$ in the epididymal region and about $22 \mathrm{~h}$ in the ductus deferens.

The daily production of spermatozoa by the testes of the quail was calculated using the estimates of 1.0 day for total transit time of $308 \times 10^{6}$ for the total extragonadal spermatozoa. The estimates were $308 \times 10^{6}$ spermatozoa per quail, $2.08 \times 10^{6}$ spermatozoa per $\mathrm{g}$ body weight and $92.5 \times 10^{6}$ spermatozoa per $\mathrm{g}$ testis.

\section{Development of motility}

Preliminary studies showed that in samples from the ductus deferens the motility of spermatozoa was depressed if there was any delay in releasing them from the duct after the 
animal's death. Consequently, to minimize the period between death and the release of spermatozoa the study was carried out as two separate experiments (Table 3).

Table 3. Mean ( \pm s.e.m.) scores of percentages of motile spermatozoa of quail $(\mathrm{N}=6)$ in samples from the testes and regions 1 to 6 of the genital ducts (see Text-fig. 1) immediately upon release into Krebs-Ringer phosphate and after incubation for 0.5 and $1 \mathrm{~h}$ at $37^{\circ} \mathrm{C}$

\begin{tabular}{|c|c|c|c|}
\hline \multirow{2}{*}{$\begin{array}{c}\text { Sampling } \\
\text { site }\end{array}$} & \multicolumn{3}{|c|}{ Duration of incubation (h) } \\
\hline & 0 & 0.5 & 1 \\
\hline \multicolumn{4}{|l|}{ Experiment 1} \\
\hline Testis & $0.3 \pm 0.2$ & $0 \pm 0$ & $0.8 \pm 0.8$ \\
\hline Region 1 & $2.5 \pm 1.7$ & $0.7 \pm 0.2$ & $0.2 \pm 0.2$ \\
\hline 2 & $18.7 \pm 11 \cdot 3$ & $13.7 \pm 7.6$ & $2.2 \pm 1.6$ \\
\hline 3 & $70 \cdot 0 \pm 7.0$ & $42 \cdot 5 \pm 8 \cdot 3$ & $33.8 \pm 11.2$ \\
\hline \multicolumn{4}{|l|}{ Experiment 2} \\
\hline 3 & $72 \cdot 1 \pm 7 \cdot 2$ & $54 \cdot 3 \pm 8 \cdot 1$ & $40 \cdot 0 \pm 8.7$ \\
\hline 6 & $82 \cdot 9 \pm 6 \cdot 3$ & $76.4 \pm 7.0$ & $60 \cdot 0 \pm 13 \cdot 1$ \\
\hline
\end{tabular}

Only a few (weakly) motile spermatozoa were found in samples from the testis. The motility of spermatozoa from the epididymal region was also weak. However, the pattern of motility of spermatozoa from these regions was the same as for 'mature' spermatozoa. There was an increase in the vigour of this motility (which roughly corresponded to changes in percentage motile spermatozoa) between the regions. It was scored as maximum for samples from the ductus deferens.

Table 3 shows the changes in mean percentage of motile spermatozoa immediately after release into Krebs-Ringer phosphate and after 0.5 and $1.0 \mathrm{~h}$ incubation. The mean scores of percentage motile increased substantially between regions 1 and $3(P<0.001)$ and showed a small increase between regions 3 and $6(P<0.01)$.

\section{Survival of spermatozoa isolated in the ductus deferens}

The effects on subsequent motility in vitro of isolating spermatozoa for various periods in the left ductus deferens are summarized in Text-fig. 2. The mean scores of percentage motile spermatozoa were much the same for samples taken from the left and right ducts of unoperated

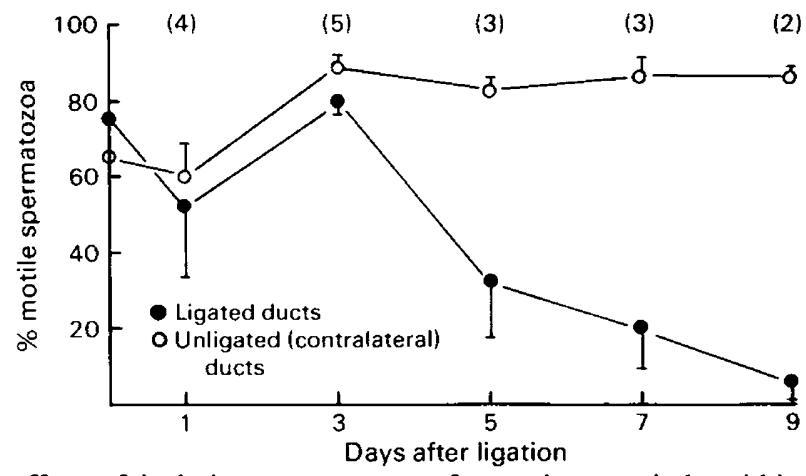

Text-fig. 2. The effect of isolating spermatozoa for various periods within the quail ductus deferens on their initial motility after dilution in Krebs-Ringer phosphate at $37^{\circ} \mathrm{C}$. Values at Day 0 are from unoperated control quail. Results are means \pm s.e.m. from 5 birds; the numbers of ligated ducts (birds) which contained motile spermatozoa are given in parentheses. 
birds (i.e. controls at time 0 , Text-fig. 2), and of birds up to 3 days after the operation. There was also no significant difference between the overall mean scores of percentage motile for samples of spermatozoa from either ducts of birds killed between 1 and 3 days after operation. However, there was a considerable reduction in the mean scores of percentage motile for samples from the ligated compared to the unligated ductus deferens $(P<0.001)$ in animals killed 5 or more days after operation. This was due to a loss of motility of all spermatozoa from some quail and an overall reduction in the percentage of motile in the others (Text-fig. 2).

The histological studies showed that in 6 birds examined 1-7 days after operation the epithelium between the ligations of a duct was structurally similar to the epithelium in the contralateral duct. This indicates that the operation did not greatly affect the integrity of the ductus deferens by, for example, restricting blood flow to the isolated region.

\section{Discussion}

The estimate for the quail of 9.5 to 10.5 days for the period of spermatogenesis between the occurrence of preleptotene and leptotene spermatocytes and spermateliosis is similar to the value determined by Amir, Braun-Eilon \& Schindler (1973), and of the same magnitude, but shorter, than the estimate for the same process in the domestic fowl (12 days; de Reviers, 1968). If it is assumed (this assumption does require verification) that this period corresponds to three cycles of the seminiferous epithelium (Amann, 1970) and that the whole spermatogenic cycle consists of about 4.5 cycles as in mammals (Setchell, 1978), then the duration of one cycle of the seminiferous epithelium would be $3 \cdot 2-3 \cdot 5$ days and the whole process of spermatogenesis from the initial spermatogonial division to sperm release from the seminiferous epithelium would be $14 \cdot 4-15 \cdot 8$ days.

The development of motility by quail spermatozoa during passage through the genital ducts appears to follow a pattern similar to that in the domestic fowl (Munro, 1938a). Because scores of the motility of spermatozoa from the genital ducts of the domestic rooster are an indication of their fertilizing capacity (Munro, 1938a), it appears that their maturation is mainly within the epididymal region of the genital ducts. Nevertheless, considering the presence of some spermatozoa from the testis which show a mature pattern of (weak) motility, which in the fowl is associated with some capacity to fertilize eggs (estimated as $0.8 \%$ by Munro, 1938a), and the short period that spermatozoa spend in the epididymal region (about $2 \mathrm{~h}$ ), it is suggested that the maturation of spermatozoa may be a much simpler process in the quail than in mammals such as the rat and rabbit (Orgebin-Crist, 1967; Dyson \& Orgebin-Crist, 1973; Robb et al., 1978). This suggestion is supported by the findings of Bedford (1979) that the spermatozoa of several non-passerine species do not appear to undergo cell surface changes in the genital ducts like those that mammalian spermatozoa undergo in the epididymis.

Since the estimate of the mean duration required for the quail spermatozoa to pass through the male genital ducts is about the same as the estimate for the shortest transit time, it is concluded that there is little mixing of spermatozoa during transit. The duration of transport and survival of quail spermatozoa in the male genital ducts are similar to the values determined by Amir et al. (1973), and of about the same magnitude (but slightly shorter) than those found for the domestic fowl (Munro, 1938a, b; de Reviers, 1968). The spermatozoa can survive at least three times as long in the male genital ducts of these birds as they take to pass through them. Furthermore, although spermatozoa may not be stored for long periods in the genital ducts, the ducts may still be considered to contain a region where spermatozoa are stored. This would be the whole ductus deferens because the spermatozoa are mature when they enter this duct, as suggested by Lake (1957), Glover \& Nicander (1971), de Reviers (1972) and Amir et al. (1973). Based on Wentworth \& Mellen's (1963) estimate of the number of spermatozoa in an ejaculate from a quail $\left(12 \times 10^{6}\right.$ spermatozoa), one male would have enough spermatozoa in the ductus deferens, every day, for about 25 ejaculations. 
Further work is required to determine whether the quail is representative of all non-passerine birds in terms of its production, transport and storage of spermatozoa. Nevertheless, the details in Table 4 show that the reproductive strategies of quail and rats are quite different: in relative terms the quail has larger testes which produce spermatozoa more rapidly, associated with a rapid transport of spermatozoa through the genital ducts and a limited capacity to store them for long periods.

Table 4. Comparison of reproductive strategies of the male quail and rat as assessed by their ability to produce, transport and store spermatozoa

\begin{tabular}{|c|c|c|}
\hline Function & Quail & Rat* \\
\hline Gonadal index $(\%)$ & $2 \cdot 26$ & 0.67 \\
\hline Spermatogenesis $\uparrow$ (days) & $9 \cdot 5-10 \cdot 5$ & $36-40$ \\
\hline \multicolumn{3}{|l|}{ Daily sperm production } \\
\hline $10^{6} / \mathrm{g}$ testis & $92 \cdot 5$ & 23.7 \\
\hline $10^{6} / \mathrm{g}$ body weight & 2.08 & 0.15 \\
\hline \multicolumn{3}{|l|}{ Duration of sperm transit (days) through: } \\
\hline genital ducts & 1 & 8.4 \\
\hline region of maturation $\ddagger$ & 0.08 & 3.4 \\
\hline region of storage $\S$ & 0.92 & $5 \cdot 0$ \\
\hline \multicolumn{3}{|l|}{ No. of extragonadal spermatozoa $\left(\times 10^{6}\right)$ : } \\
\hline per animal & 308 & 735 \\
\hline in region of maturation & $23(8 \%)$ & $295(40 \%)$ \\
\hline in region of storage & $285(92 \%)$ & $440(60 \%)$ \\
\hline Sperm survival in isolated duct (days) & $5-9$ & 42 \\
\hline
\end{tabular}

* Values calculated from Robb et al. (1978) for 125-day-old Wistar rats except for spermatogenic values which were calculated from Courot, Hochereau-de Reviers \& Ortavant (1970), and the sperm survival value which was taken from White (1932).

$\dagger$ Period from preleptotene/leptotene spermatocytes to their release from the seminiferous epithelium.

$\ddagger$ Head and body of rat epididymis; epididymal region of quail.

$\S$ Tail of rat epididymis; ductus deferens of quail.

We are indebted to Dr R. A. E. Pimm, Poultry Research Station, Department of Agriculture, Seven Hills, New South Wales, for donating the quail, and to the Australian Research Grants Committee and the Internal Assessment Research Committee for financial support.

\section{References}

Aire, T.A. (1979) The epididymal region of the Japanese quail (Coturnix coturnix japonica). Acta anat. 103, 305-312.

Aire, T.A. (1980) The ductuli efferentes of the epididymal region of birds. J. Anat. 130, 707-723.

Amann, R.P. (1970) Sperm production rates. In The Testis, Vol. 1, pp. 433-482. Eds A. D. Johnson, W. R. Gomes \& N. L. VanDemark. Academic Press, New York.

Amir, D., Braun-Eilon, B. \& Schindler, H. (1973) Passage and disappearance of labelled spermatozoa in the genital tract of the male Japanese quail in segregation or cohabitation. Annls Biol. anim. Biochim. Biophys. 13, 321-328.

Bedford, J.M. (1979) Evolution of the sperm maturation and sperm storage functions of the epididymis. In
The Spermatozoon. Maturation, Motility, Surface Properties and Comparative Aspects, pp. 7-21. Eds D. W. Fawcett \& J. M. Bedford. Urban and Schwarzenberg, Baltimore.

Courot, M., Hochereau-de Reviers, M.-T. \& Ortavant, R. (1970) Spermatogenesis. In The Testis, Vol. I, pp. 339-432. Eds A. D. Johnson, W. R. Gomes \& N. L. VanDemark. Academic Press, New York.

de Reviers, M. (1968) Determination de la durée des processus spermatogénétiques chez le coq à l'aide de thymidine tritiee. Proc. 6th Int. Congr. Animal Reprod. \& A.I., Paris Vol. I, pp. 183-185.

de Reviers, M. (1972) Evaluation des reserves spermatiques dans les voies déférentes du Coq. Annls Biol. anim. Biochim. Biophys. 12, 5-11.

Dyson, A.L.M.B. \& Orgebin-Crist, M.C. (1973) Effect 
of hypophysectomy, castration and androgen replacement upon the fertilizing ability of rat epididymal spermatozoa. Endocrinology 93, 391-402.

Emmens, C.W. (1947) The motility and viability of rabbit spermatozoa at different hydrogen ion concentrations. J. Physiol, Lond. 106, 471-481.

Glover, T.D. \& Nicander, L. (1971) Some aspects of structure and function in the mammalian epididymis. J. Reprod. Fert., Suppl. 13, 39-50.

Hess, R.A. \& Thurston, R.J. (1977) Ultrastructure of the epithelial cells in the epididymal region of the turkey (Meleagris gallopavo). J. Anat. 124, 765-778.

Hess, R.A., Thurston, R.J. \& Biellier, H.V. (1976) Morphology of the epididymal region and ductus deferens of the turkey (Meleagris gallopavo). J. Anat. 122, 241-252.

Lake, P.E. (1957) The male reproductive tract of the fowl. J. Anat. 91, 116-129.

Munro, S.S. (1938a) Functional changes in fowl sperm during their passage through the excurrent ducts of the male. J. exp. Zool. 79, 71-92.

Munro, S.S. (1938b) The effect of testis hormone on the preservation of sperm life in the vas deferens of the fowl. J. exp. Biol. 15, 186-196.

Orgebin-Crist, M.-C. (1965) Passage of spermatozoa labelled with thymidine $-{ }^{3} \mathrm{H}$ through the ductus epididymidis of the rabbit. J. Reprod. Fert. 10, 241-251.
Orgebin-Crist, M.-C. (1967) Maturation of spermatozoa in the rabbit epididymis: fertilizing ability and embryonic mortality in does inseminated with epididymal spermatozoa. Annls Biol. anim. Biochim. Biophys. 7, 373-389.

Robb, G.W., Amann, R.P. \& Killian, G.J. (1978) Daily sperm production and epididymal sperm reserves of pubertal and adult rats. J. Reprod. Fert. 54, 103-107.

Setchell, B.P. (1978) Spermatogenesis. In The Mammalian Testis, pp. 181-232. Elek, London.

Tingari, M.D. (1971) On the structure of the epididymal region and ductus deferens of the domestic fowl (Gallus domesticus). J. Anat. 109, 423-435.

Tingari, M.D. (1972) The fine structure of the epithelial lining of the excurrent duct system of the testis of the domestic fowl (Gallus domesticus). $Q$. $J l$ exp. Physiol. 57, 271-295

Umbreit, W.W., Burris, R.H. \& Staufier, J.F. (1972) Manometric and Biochemical Techniques. 5th edn, p. 146. Burgess Publ. Co., Minneapolis.

Wentworth, B.C. \& Mellen, W.J. (1963) Egg production and fertility following various methods of insemination in Japanese quail (Coturnix coturnix japonica). J. Reprod. Fert. 6, 215-220.

White, W.W. (1932) The effect of hypophysectomy on the survival of spermatozoa in the male rat. Anat. Rec. 54, 253-273.

Received 3 February 1981 